\title{
COOPETITION STRATEGY FOR ENHANCING THE SUSTAINABILITY OF FAMILY OWNED KIRANAS IN THE VOLATILE, UNCERTAIN, COMPLEX AND AMBIGUOUS (VUCA) INDIAN RETAIL INDUSTRY
}

\author{
C. Mathan ${ }^{1}$, G. Balamurugan ${ }^{2}$ and J. Praveen Paul ${ }^{3}$ \\ Department of Management Studies, Mepco Schlenk Engineering College, India \\ E-mail: ${ }^{1}$ mathan@mepcoeng.ac.in, ${ }^{2}$ gbala@mepcoeng.ac.in, 3jpraveenpaul@mepcoeng.ac.in
}

\begin{abstract}
Agrarian based Indian economy currently turned into a service based economy. Liberalization of Indian economy as well as present government's retail sector policy paves way for big organized retailers' to enter and also expand in the Indian retail market. Currently Indian retail market is dominated by unorganized, family owned kiranas, which hold almost $88 \%$ market share. Entry of new big organized players and expansion of existing big players will bring in conflict of interest with the currently dominating kiranas, who provide major employment. This paper discusses about adaptation of coopetition strategy by big organized retailers and kiranas, mainly to mitigate such conflict of interest. As per the strategy, organized big retailers will be the wholesaler for kiranas and kiranas will be the last mile distributor for the big player. Information Communication Technology (ICT) shall bridge the organized and unorganized retailers and play a major role in implementing coopetition strategy. A study was conducted among 272 Kiranas of southern districts of Tamil Nadu to check the feasibility of coopetition strategy. From the study, it is found that most of the Kiranas are ready to adapt "Coopetition strategy". This strategy will curtail the big organised retailers' investments in distribution network. At the same time kiranas will not lose their proximate customers business, even if the customer's order their requirements through E-retail system.
\end{abstract}

Keywords:

Retailing, Family Owned Kiranas, ICT, Coopetition

\section{INTRODUCTION}

Currently, theservice sector's contribution to the Indian Gross Domestic Product (GDP) is around 64\% for the FY 2015-16. Trade, hotels, transport and communication alone contributed 12.6\% [4]. Agrarian based Indian economy is slowly changing into a service based economy.

The estimated CAGR (2013-19) of Indian GDP is 6.5\%. Retail market is growing at a rate of $13 \%$ and faster than the GDP [1]. Indian organized retailers' market share is $11.4 \%$ of USD 632 billion Indian retail market [1], but in developed nations it is 65 85\% [2].

India has about 75 million middle class households and their disposable income is in an increasing trend. India tops in the estimated personal disposable income growth with a CAGR (201318) of $13 \%$. India ranks second in millionaires growth and has 1.5 Lakh millionaires [16]. Growth in personal disposable income is good for the retailing industry since purchasing power of people is increasing.
$70 \%$ of the Indian population lives in Rural India. They consume only $40 \%$ of total Indian consumption. This may be due to minimal presence of organized retailing [16]. Thus there is a significant scope for the Indian organized retail sector to expand in rural as well as in urban market.

India achieved second rank among 30 developing countries in 2016 Global Retail Development Index (Index based on countries attractiveness and the future potential in retail industry).

Post-Liberalization, Indian government relaxed norms for FDI in retail sector [15]. Recently Government permitted 100\% FDI in online market place retailing and 51\% FDI in multi-brand retail outlets [16]. However, online market place retailers will not be allowed to use aggressive discounting as a weapon for increasing sales [3].

India's consistent economic growth, easing out FDI norms attracts many multinational retailers such as Metro, Amazon, IKEA, Wal-Mart, etc. During 2000-2016, Indian retail market received total FDI inflow of USD 537.61 billion [7]. Present conducive operating environment paves way for existing big organized retailers such as Reliance, Big bazaar, Wal-Mart, IKEA to expand. E-retailers like Flipkart, Snapdeal and Amazon are also expanding their presence.

Ironically, already there are about 14 million family managed and operated small unorganized kiranas, who handle about $88 \%$ of the Indian retail market and significantly major employment creators. Expansion and entry plans organized online and offline retailers may lead to conflictof interest with the existing kiranas [1].

By 2020 the Indian organized retail sector is expected to account for 24\% market share with an expected CAGR of $20 \%$ [6]. Without including kiranas, this growth, may lead to unrest in Indian retail industry. Hence a sustainable business model has to be evolved to benefit both organized retailers and unorganized kiranas.

\section{RELATED LITERATURE}

Future of Indian retail market is very attractive, but currently organized retailers are not doing well. Reliance retail has seen profit only after seven years of waiting since 2006. Biyani’s Future retail arm and Tata's Trent are yet to make profits [7]. Flipkart made Rs. 2000Cr loss in FY 2015. Snapdeal lost Rs. 1350 Cr and Amazon too lost money [19].

Presently, India retailers are in a highly fragmented state. In offline organized retail sector, Reliance ranked first with a turnover of Rs.18, 000 Cr or USD 3 billion in a USD 632 billion market. Reliance's market share is just 0.5\% [5].

Out of the estimated 14 million unorganized outlets, only $4 \%$ are having more than $500 \mathrm{sq} \mathrm{ft}$, shops. Most of them are family owned or family operated shops [16]. 
This shows the existing level of fragmentation in the industry and automatically forces the top players to go for consolidation. Currently Aditya Birla group is consolidating its retail businesses and is planning to add 200 more stores. Bharti retail and Biyani's Future retail are also consolidating their businesses [5].

Currently Flipkart (45\%), Snapdeal (20\%) and Amazon (12\%) are the major online retailers in India and together hold a market share of $77 \%$. Already there are rumors spreading on merger between Flipkart and Snapdeal.

Organized as well as unorganized retailers are facing stiff competition from domestic as well as foreign retailers. To face the competition and alsoto come out of their losses, organized retailers are taking the strategy of consolidating.

On one hand, retailers are facing competition and in the other hand they need to cope with the customers' tastes and preferences. Indian customers' technology adaptation rate is faster than the retail industry. With the advent of Information Communication Technology (ICT), internet penetration, vigorous smart phone penetration and convenient shopping make the millennial high income group prefer online shopping [8]. For the past couple of years online retail sector is growing at a phenomenal rate of $45 \%$ [17]. Despite the rise of e-commerce, m-commerce and social media, customers also prefer traditional brick and mortar stores for purchasing their goods [9].

To entice online and offline customers, big organized retailers transmute into omni-channel (OC) format by implementing ICT. Omni channel format, forces retailer's presence in online as well as in offline, with door delivery facility.

Door delivery of items ordered digitally, will be economically feasible only with higher physical outlet density [9]. Opening up of more physical stores by OC retailers increases their bottomline. Surprisingly their online sales do not get affected. Noticeably majority of the grocery shoppers visit online retail sites for searching information and they purchase from offline stores. So this customer behavior forces OC retailers to follow the same pricing strategy for online, as well as offline channels and to keep both channels [10].

Due to its inherent complexity, adding channels either synergizes or cannibalizes big organized retailers. Synergy depends on the retailer's ability in integrating channels, better interaction between channels, cooperation in advertisement, efficiency in distributing goods and the harmonized communication with their customers [11].

As a new strategy, Amazon recently introduced "click and collect" scheme in USA which allow the customer to make online order and collect the ordered item from the store. Formerly Amazon, USA was losing money but now it is making profit consecutively for the past three quarters. Already all kinds of retail formats are looking for OC route to sustain their business [12]. In India Reliance is looking at the online retailing option too but Future group scaled back its E-retailing plans [18].

In the process of transmuting into OC, big organized retailers can capitalizethe advantages of kiranas, by partnering with them. Family managed and operated kiranas have advantages such as proximity to customers, offering credit, door delivery, good customer relationship, highly motivated owner cum labor and customized services.
Apart from this, kiranas have low operating cost, better and intimate understanding of customers' needs which cannot be substituted by any other retailing format.

Especially Indians have the habit of buying when required, instead of planning in advance. This habit makes the customers to visit the kiranas frequently and this reinforces existing relationship. Since kiranas completely know about the requirements of their proximate customers, they know, what to store. This valuable information leads to lean inventory. In this regard OC retailers can't compete with kiranas.

OC retailers have advantages like huge financial resources, better technology, state of art warehousing and world class supply chain management [13]. By adopting coopetition strategy, OC retailers' and kiranas' advantages can be combined to have a synergy effect to the retail industry.

\section{NEED FOR THE STUDY}

The previous literature and the below mentioned developments in the retail sector of India demanded this study.

\subsection{VOLATILITY IN INDIAN RETAIL FORMAT}

Volatility in Indian retail sector is more since the new entrants bring in modern retail format such as malls, supermarket, hypermarket, online- retailing and etc. Few examples are Amazon, Flipkart, Snapdeal, BigBasket, Wal-Mart, Reliance Mart, Big Bazaar, Pantaloons Tata Chrome stores and etc. Since these new formats are accepted by customers Indian retail sector is growing faster than Indian GDP.

Not only new formats are getting introduced but also technological innovations. Some of the innovations are enterprisere source planning, sales force automation, radio frequency identification, E-catalogue based selling and mobile point of sale. This shows that organized retail sector is in its growth phase. Once it reaches maturity phase one can expect consolidation. Even during its growth stage consolidation is happening [21].

\subsection{UNCERTAINTY IN PROFITABILITY}

Developing country markets like India are totally different from those of developed countries. Indians' purchasing habits are different from developed countries and varying from regions to region. Indian customers are price sensitive. So profitability of Indian organized sector is a big question, however presently their brand consciousness is slowly increasing [24].

Amazon made a net loss of Rs. 1724 Cr even after a 600\% increase in theirsales for the FY 2015. Physical stores like WalMart are also going through severe losses. All the three major online retailers made combined losses to the tune of Rs. 5052Cr. Organized retailers increased, their sales only through deep discount model. Financial feasibility of deep discount model is not certain.

\subsection{COMPLEXITY IN GOVERNMENT'S FDI POLICY}

In India, retailing is classified into several segments such as single-brand, multi-brand, wholesale and e-commerce. The 
complexity arises, when each segment is governed by separate FDI policies. This creates confusion for the potential foreign players. For example in the case of multi brand foreign equity $51 \%$ FDI is allowed, however only about $50 \%$ of the Indian states have agreed to allow such entity. With this kind of complexity, even to establish a regional supply chain, foreign players will find it difficult [22].

\subsection{COMPLEXITY IN CUSTOMER'S TASTES AND PREFERENCES}

Young consumers and high tax payers prefer the emerging retail formats such as malls, super markets, hypermarts and specialty stores for shopping purposes. However older consumers and no tax payers prefer traditional retail formats such as convenience store, discount stores and departmental stores [23].

\subsection{AMBIGUITY IN RETAILER'S STRATEGIC DECISIONS}

Earlier Wal-Mart had an idea of entering into the online space but now only they are exploring ways to tie-up with E-commerce companies like Flipkart, Snapdeal, BigBasket and etc. [26]. Big groups like Reliance, Tata are looking at the online retailing option, however Future group scaled back its E-commerce plans. For survival online players are planning to get into brick and mortar and vice versa [18].

However, in this current VUCA Indian retail industry to stay in the business big organized retailers may have to transmute themselves into Omni-Channel. As discussed earlier, this could raise to the clash of interest between expanding organised OC retailers and existing unorganized kiranas. It is imperative to avoid such clash otherwise will lead to industry unrest. Organized as well as unorganized retailers should look out for an appropriate, sustainable business model which will complement each other and reduce conflict. Organised retailers and kiranas could consider working together as partners not as competitors. Coopetition strategy might work by combining and aggrandizing the advantages of organised retailers and kiranas, while alleviating their disadvantages.

\section{COOPETITION CONCEPT}

Coopetition strategy is a hybrid strategy named after combining competition and cooperation. This kind of inter-firm interdependence strategy creates synergy among firms. Coopetition originally meant for inter firm cooperation between the firm and its suppliers, customers and complementors, however in addition to these three groups competitors were included by Brandenburger and Nalebuff [20].

Coopetition strategy is already adapted in automobile industry. First time this strategy is conceptually adapted for Indian retail industry that too among competitors. OC retailers and kiranas can go for a partnership arrangement at a macro level. Definitely coopetition strategy will be a win-win for both OC retailers and kiranas. The conceptual coopetition brick and click model, is pictorially explained in Fig.1 [14].

Stepwise explanation for coopetition strategy is mentioned as,

1. Kiranas can purchase their entire requirement from OC retailers. Currently kiranas deal with many wholesalers for purchasing their requirements. Treating OC retailer as a one stop shop shall save lots of time and money for kiranas.

2. Households can order their requirement digitally to OC retailer. Further the order shall betransferredto the partner kirana, whoever is nearer to the customer's place. Kirana, who has already stocked the OC retailer's goods, shall deliver the ordered item at the doorsteps of the customer. Thus the customer gets the OC retailer's goods. In this way kiranas support OC retailer in the last mile distribution.

3. For delivering the digitally ordered items, kiranas have three options.

- Kirana can deliver the ordered item through his employees.

- Kirana can deliver the ordered item through newspaperman, who visits households every day.

- Kirana can deliver the ordered item through milkmen, who visit households every day.

4. Households can buy their requirements from the kiranas directly or they can digitally order their requirement through E-retailing system for a home delivery. Thus OC retailer and kiranas together create a system to entice online customers as well as the customers, who would like to visit the store. In this arrangement quality products shall be available nearer to the customer's place.

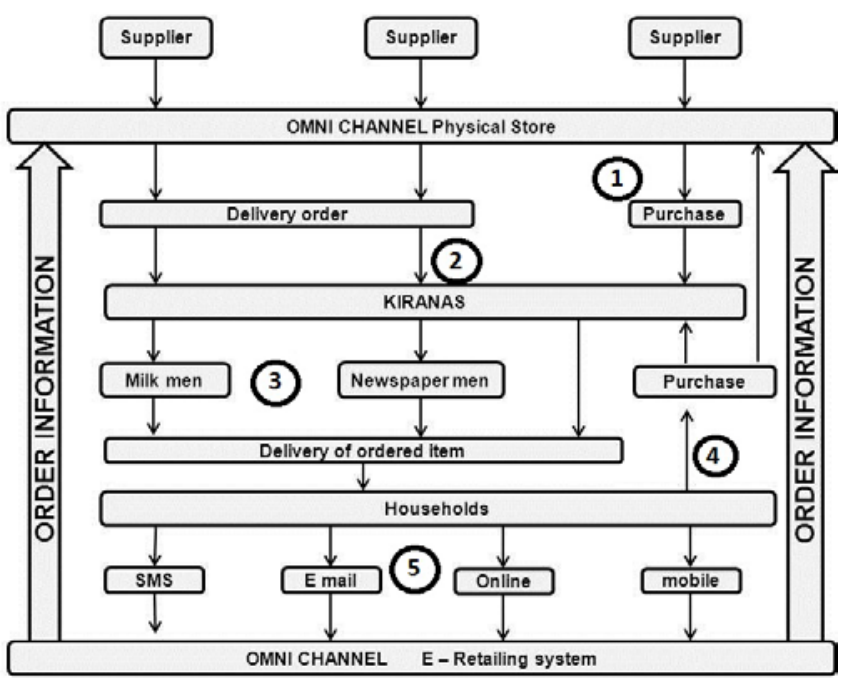

Fig.1. Coopetition Brick and Click Model

This Coopetition Brick and Click Model combine the advantages of big organised retailer and kiranas, which is pictorially represented in Fig.2.

OC retailer has advantages like world class procurement, better technology and more assortments. Since personal disposable income and brand consciousness is on an increasing trend customers are looking for quality products.

Kiranas are very near to the customer. With less investment and low operating cost they can operate their stores. They know their customers personally and their requirements. So kiranas stock only the required item and this lead to a lean inventory.

By coopetition strategy both OC retailer and kirana can enjoy each other's advantages. OC retailers can avoid huge investments 
in physical store expansion and also in setting up distribution network. Kiranas purchase their complete requirement from OC retailers. Since kiranas home deliver the proximate customer's order, received through OC retailers' E-retail system from his stocks. Kiranas usual business will not be lost even if his proximate customer orders through e-retail system. OC retailers support kiranas by providing the latest ICT for communicating, the digitally received orders and for knowing the inventory level of kiranas. Kiranas can enjoy OC retailer's world level procurement and cheaper cost.

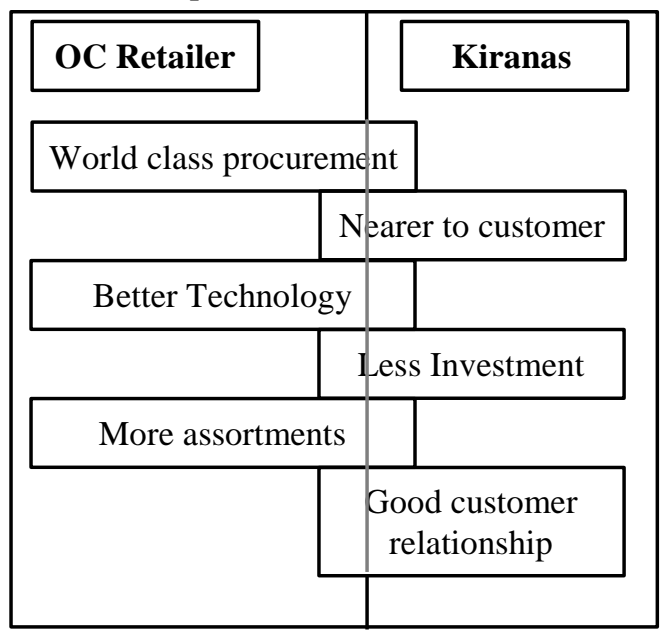

Fig.2. Advantages of OC Retailer and Kiranas

\section{RESEARCH METHODOLOGY}

A research study was conducted to empirically test the above said (Fig.1) Coopetition brick and click model among 272 small retailers from southern part of Tamil Nadu.

Primary data were collected through a structured questionnaire from the small and medium retailers.

Table.1. Locality

\begin{tabular}{|l|c|}
\hline \multicolumn{1}{|c|}{ Locality } & No. of retailers \\
\hline Rural & 79 \\
\hline Urban & 193 \\
\hline Total & 272 \\
\hline
\end{tabular}

Primary data collected mostly from urban retailers. These retailers purchase their requirements from 23 wholesalers. Mostly the wholesalers are nearby and few of them visit their stores and supply the goods to kiranas.

Table.2. Credit facility by Kiranas

\begin{tabular}{|l|c|c|c|}
\hline Credit facility & Rural & Urban & Total \\
\hline Collateral & 9 & 6 & 15 \\
\hline Trust & 70 & 187 & 257 \\
\hline Total & 79 & 193 & 272 \\
\hline
\end{tabular}

Almost $70 \%$ of the kiranas opined that they provide credit to their customers based on trust since they have cordial relationship with them.

Table.3. Organized retailer’s presence

\begin{tabular}{|l|c|c|c|}
\hline $\begin{array}{c}\text { Organized retailers } \\
\text { Presence }\end{array}$ & Rural & Urban & Total \\
\hline Afraid & 34 & 66 & 100 \\
\hline Not Afraid & 45 & 127 & 172 \\
\hline Total & 79 & 193 & 272 \\
\hline
\end{tabular}

May be because of such stronger relationship with their customers most of the kiranas are not much afraid of big organized retailers' presence. Compared to urban rural kiranas are more afraid on the presence of organized retailers.

\subsection{PRESENCE OF BIG ORGANISED RETAILERS VS THE STORE SIZE}

To analyse the significant difference between the opinion on kirana's fearfulness on the presence of big organised retailers and the store size of the kiranas cross tabulation is made also ChiSquare test is applied.

Table.4. Cross tabulation between store size of the kirana and their fearfulness on the presence of OC retailers

\begin{tabular}{|c|c|c|c|c|}
\hline \multicolumn{2}{|c|}{ Store size in Sq.ft. $\begin{array}{r}\begin{array}{r}\text { Kiranas fearfulness } \\
\text { of } \mathrm{OC} \text { retailers }\end{array} \\
\text { the presence }\end{array}$} & \multirow{2}{*}{$\begin{array}{l}\text { No } \\
25\end{array}$} & \multirow{2}{*}{$\begin{array}{l}\text { Yes } \\
17 \\
17\end{array}$} & \multirow{2}{*}{$\begin{array}{c}\text { Total } \\
42\end{array}$} \\
\hline \multirow{4}{*}{$\begin{array}{l}\text { Big } \\
>500\end{array}$} & Count & & & \\
\hline & $\%$ within store size & $59.5 \%$ & $40.5 \%$ & $100.0 \%$ \\
\hline & \% within Afraid & $14.5 \%$ & $17.0 \%$ & $15.4 \%$ \\
\hline & $\%$ of Total & $9.2 \%$ & $6.2 \%$ & $15.4 \%$ \\
\hline \multirow{4}{*}{$\begin{array}{l}\text { Medium } \\
101-500\end{array}$} & Count & 99 & 54 & 153 \\
\hline & \% within store size & $64.7 \%$ & $35.3 \%$ & $100.0 \%$ \\
\hline & $\%$ within Afraid & $57.6 \%$ & $54.0 \%$ & $56.2 \%$ \\
\hline & $\%$ of Total & $36.4 \%$ & $19.9 \%$ & $56.2 \%$ \\
\hline \multirow{4}{*}{$\begin{array}{l}\text { Small } \\
<100\end{array}$} & Count & 48 & 29 & 77 \\
\hline & $\%$ within store size & $62.3 \%$ & $37.7 \%$ & $100.0 \%$ \\
\hline & $\%$ within Afraid & $27.9 \%$ & $29.0 \%$ & $28.3 \%$ \\
\hline & $\%$ of Total & $17.6 \%$ & $10.7 \%$ & $28.3 \%$ \\
\hline \multirow{4}{*}{ Total } & Count & 172 & 100 & 272 \\
\hline & $\%$ within store size & $63.2 \%$ & $36.8 \%$ & $100.0 \%$ \\
\hline & $\%$ within Afraid & $100.0 \%$ & $100.0 \%$ & $100.0 \%$ \\
\hline & $\%$ of Total & $63.2 \%$ & $36.8 \%$ & $100.0 \%$ \\
\hline
\end{tabular}

Source: Primary data

From the analysis, it is found that $40.5 \%$ of the big size kiranas, $37.7 \%$ of the small size and $35.3 \%$ of the medium size kiranas are afraid about the presence of big organized retailer. 
The null hypothesis that there is no significant difference between the store size of the kirana and their fearfulness on the presence of OC retailers, is considered for Chi-Square test.

Table.5. Chi-Square Test for store size of the kirana and their fearfulness on the presence of OC retailers

\begin{tabular}{|l|c|c|c|}
\hline \multicolumn{1}{|c|}{ Measures } & Value & $\begin{array}{c}\text { Degrees of } \\
\text { freedom }\end{array}$ & $\begin{array}{c}\text { Asymptotic } \\
\text { Significance } \\
\text { (2-sided) }\end{array}$ \\
\hline Pearson Chi-Square & $.418^{*}$ & 2 & .811 \\
\hline Likelihood Ratio & .415 & 2 & .812 \\
\hline N of Valid Cases & 272 & & \\
\hline * 0 cells (0.0\%) have expected count less than 5. \\
The minimum expected count is 29.04. \\
\hline
\end{tabular}

Source: Primary data collected

Since the asymptotic significance is greater than 0.05 , we accept the null hypothesis. We could infer from the analysis that the kiranas fearfulness on the presence of big organized retailers is not affected by the store size of the kiranas.

\subsection{WILLINGNESS TO PARTNER VS THE LOCALITY OF THE KIRANAS}

To analyse the significant difference between the opinion on the willingness to partner with big organized retailer and the locality of the kiranas cross tabulation is made and further ChiSquare test is applied.

Table.6. Cross tabulation between locality of the kirana and their willingness to partner with OC retailer

\begin{tabular}{|c|c|c|c|c|}
\hline \multicolumn{2}{|c|}{$\begin{array}{r}\text { Willingness of the kirana } \\
\text { to partner with } \\
\text { OC retaile }\end{array}$} & \multirow{2}{*}{$\begin{array}{c}\text { No } \\
21\end{array}$} & \multirow{2}{*}{$\begin{array}{l}\text { Yes } \\
58\end{array}$} & \multirow{2}{*}{$\begin{array}{c}\text { Total } \\
79\end{array}$} \\
\hline \multirow{3}{*}{ Rural } & Count & & & \\
\hline & $\%$ within Locality & $26.6 \%$ & $73.4 \%$ & $100 \%$ \\
\hline & $\%$ of Total & $7.7 \%$ & $21.3 \%$ & $29 \%$ \\
\hline \multirow{3}{*}{ Urban } & Count & 29 & 164 & 193 \\
\hline & $\%$ within Locality & $15.0 \%$ & $85.0 \%$ & $100 \%$ \\
\hline & $\%$ of Total & $10.7 \%$ & $60.3 \%$ & $71 \%$ \\
\hline \multirow{3}{*}{ Total } & Count & 50 & 222 & 272 \\
\hline & $\%$ within Locality & $18.4 \%$ & $81.6 \%$ & $100 \%$ \\
\hline & $\%$ of Total & $18.4 \%$ & $81.6 \%$ & $100.0 \%$ \\
\hline
\end{tabular}

Source: Primary data

From the analysis, it is found that $81.6 \%$ of kiranas (222 out of 272) say that they are willing to partner with big organized retailer to adapt coopetition strategy. Out of 79 rural kiranas, $73.4 \%$ (58 out of 79) say that they are willing to partner with big organized retailer. Out of 193 urban kiranas, 81.6\% (164 out of 193) say that they are willing to partner with big organized retailer. It could be inferred from the above discussion that majority of the kiranas are willing to partner with big organized retailer to adapt coopetition strategy.

The null hypothesis that, there is no significant difference between the locality of the kirana and their willingness to partner with OC retailer is considered for the test.

Table.7. Chi-Square Test for locality of the kirana and their willingness to partner with OC retailer

\begin{tabular}{|l|c|c|c|}
\hline \multicolumn{1}{|c|}{ Measures } & Value & $\begin{array}{c}\text { Degrees of } \\
\text { freedom }\end{array}$ & $\begin{array}{c}\text { Asymptotic } \\
\text { Significance } \\
\text { (2-sided) }\end{array}$ \\
\hline Pearson Chi-Square & $4.990 *$ & 1 & .025 \\
\hline Likelihood Ratio & 4.735 & 1 & .030 \\
\hline N of Valid Cases & 272 & & \\
\hline * 0 cells (0.0\%) have expected count less than 5. \\
The minimum expected count is 14.5
\end{tabular}

Source: Primary data

While observing the results from the Chi-Square test exhibited in Table.2, the asymptotic significance is less than 0.05 ( $p>0.05$ ). So we reject the null hypothesis and conclude that there is a significant difference between the locality of the kirana and their willingness to partner with OC retailer.

Table.8. Milkman Services

\begin{tabular}{|l|c|c|c|}
\hline Milkman & Rural & Urban & Total \\
\hline Use & 28 & 53 & 81 \\
\hline Not to use & 51 & 140 & 191 \\
\hline Total & 79 & 193 & 272 \\
\hline
\end{tabular}

From the table we can infer that $70 \%$ (193 out of 272) of the kiranas are not willing to distribute the ordered item through milk man or Newspaper men. Kiranas would like to distribute by their own employees.

\section{FINDINGS AND CONCLUSION}

From the study we can infer that kiranas are interested in adapting Coopetition strategy and partner with big organized retailers for purchasing their requirements and to be the last mile distributor for big organized retailers. Compared to rural, urban kiranas are more willing to partner with big organised retailers.

However, for distributing ordered goods kiranas would like to distribute the goods by their employees only. They do not want to utilize the services of Milkmen in distributing the ordered goods.

From the study and findings researchers modify the earlier proposed coopetition Brick and Click model [14] and propose the new model as mentioned in Fig.3. 


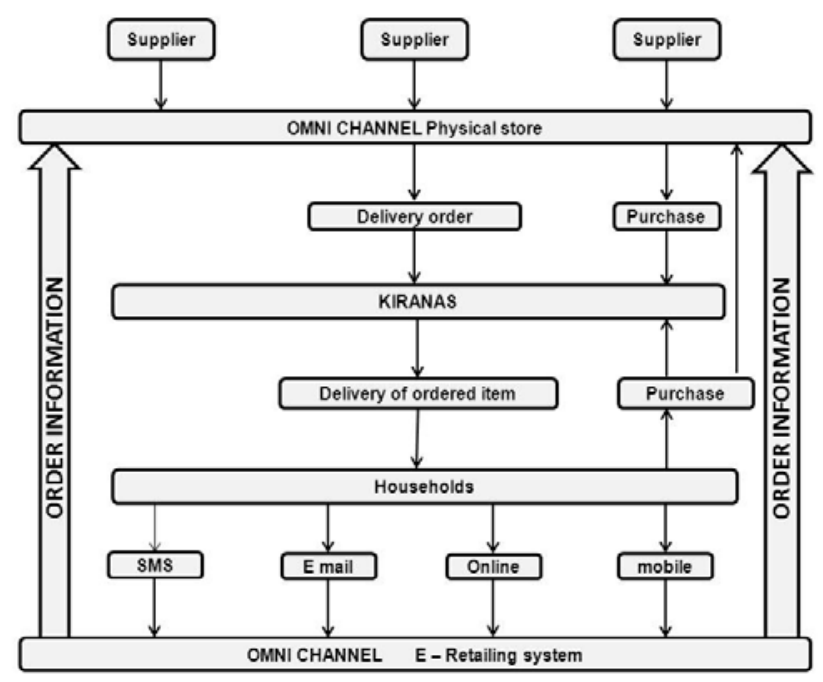

Fig.3. Modified Brick and Click Model

For further study the researchers can conducta survey among big organized retailers in adapting coopetition strategy. Till now most of the big organised retailers are making losses only. So the future study will have a good impact in Indian retail industry.

\section{ACKNOWLEDGEMENT}

We whole heartedly thank the authorities of Mepco Schlenk Engineering College, Sivakasi for their support in writing this article.

\section{REFERENCES}

[1] Amitabh Mall, Rachit Mathur and Namit Puri, "Decoding Digital @ Retail: Winning the Omni-Channel Consumer with Digital in Retail”, Available at: www.bcg.com, Accessed on 12 Mar 2016.

[2] Jones Lang LaSalle, "Retail Realty in India: Evolution and Potential, A Comparison and Contrast with the Emerging Cities of Asia”, Global Insight, Real Estate Intelligence 4Q13, 2014.

[3] PTI, "Recent FDI norms to Benefit Offline Retailers: Crisil", Available at: www.economictimes.indiatimes.com, Accessed on 17 March 2016.

[4] IBEF, "Service Sector in India”, Available at: www.ibef.org, Accessed on 17 August 2016.

[5] Ramnath Subbu, "Organised Retail Reorganising in India”, Available at: www.thehindu.com/business/Industry/retailsector-in-india/article7188691.ece, Accessed on 17 January 2016.

[6] IBEF, "Retail Industry in India, Retail Sector in India, Indian Retail Industry”, Available at: www.ibef.org, Accessed on 17 august 2016.

[7] Deepak Ajwani, “Supermarkets can't Compete with Kiranas: SCA India head Cecilia Edebo", Available at: www.forbesindia.com, Accessed on 17 March 2016.

[8] Steve Baggi, “The Revolution will be Digitized”, Journal of Direct Data and Digital Marketing Practice. Vol. 16, No. 2, pp. 86-91, 2014.

[9] Rafay Ishfaq, C. Clifford Defee, Brian J Gibson and Uzma Raja, "Realignment of the Physical Distribution Process in Omni-channel Fulfillment”, International Journal of
Physical Distribution \& Logistics Management, Vol. 46, No. 6/7, pp. 543-561, 2016.

[10] M. Kimpel and C. Friedrich, “The Right Pricing Strategy for Offline Retailers when Expanding into the Online Sales Channel”, Journal of Business and Retail Management Research, Vol. 9, No. 2, pp. 54-67, 2015.

[11] Peter C. Vehhoef, P.K. Kannan and J. Jeffrey Inman, "From Multi-Channel Retailing to Omni-Channel Retailing”, Journal of Retailing, Vol. 91, No. 2, pp. 174-181, 2015.

[12] Krystina Gustafson, "Retail’s Big Advantage over Amazon Isn't Foolproof”, Available at: www.cnbc.com, Accessed on 17 August 2016.

[13] Gordhan K. Saini and Arvind Sahay, "Comparing Retail Formats in an Emerging Market: Influence of Credit and Low Price Guarantee on Purchase Intention”, Journal of Indian Business Research, Vol. 6, No. 1, pp. 48-69, 2014.

[14] C. Mathan, G. Balamurugan and J. Praveen Paul, "Brick \& Click Retail Model-Small Retailers Perspective in India”, Proceedings of National Seminar on Innovative Management Strategies for Future Markets, 2014.

[15] PTI, "India ranks second on retail ind index on ease of doing business: study", Available at: www.thehindubusinessline.com/economy/india-rankssecond-on-grd-index-on-ease-of-doing-businessstudy/article8696425.ece, Accessed on Nov 1, 2016.

[16] KPMG, "Indian Retail The Next Growth Story", Available at:

www.kpmg.com/IN/en/IssuesAndInsights/ArticlesPublicati ons/Documents/BBG-Retail.pdf, Accessed on 7th November, 2016.

[17] Anurag Mathur, “Are you Profitability Ready? Perspectives on the Indian Retail Industry”, Available at: www.pwc.in/.../are-you-profitability-ready-perspectiveson-the-indian-retail-in, Accessed on 7th November, 2016.

[18] The Economist, "The Great Race", Available at: www.economist.com/node/21693921, Accessed on 3 November 2016.

[19] Minhaz Merchant, "Flipkart-Snapdeal Merger: Bad Idea”, Available at: http://businessworld.in/article/FlipkartSnapdeal-Merger-Bad-Idea/19-07-2016-100577/, Accessed on 3 November 2016.

[20] Adam M. Brandenburger and Harbourne W. Stuart Jr., "Value-Based Business Strategy", Journal of Economics \& Management Strategy, Vol. 5, No. 1, pp. 5-14, 1996.

[21] Anand Ramu Patil, "Retailing Innovations in India", The Academy of Business and Retail Management, Vol. 2, No. 1, pp. 151-156.

[22] Rasul Bailay, "India has One of the Most Complex Policies when it comes to Retail”, The Economic Times, Available at:

http://economictimes.indiatimes.com/industry/services/retai 1/india-has-one-of-the-most-complex-policies-when-itcomes-to-retail/articleshow/54474677.cms, Accessed on 7th November, 2016.

[23] Rasul Bailay, "India has One of the Most Complex Policies when it comes to Retail”, The Economic Times, Available at:

http://economictimes.indiatimes.com/industry/services/retai 1/india-has-one-of-the-most-complex-policies-when-it- 
comes-to-retail/articleshow/54474677.cms, Accessed on 7th November, 2016.

[24] Deepika Jhamb and Ravi Kiran, “Trendy Shopping Replacing Traditional Format Preferences”, African Journal of Business Management, Vol. 6, No. 11, pp. 4196-4207, 2012.

[25] Arpita Mukherjee, et al., "Are Indian Consumers Brand Conscious? Insights for Global Retailers”, Asia Pacific Journal of Marketing and Logistics, Vol. 24, No. 3, pp. 482499, 2012.
[26] Mehr, "Is India’s Organized Retail Sector a Profitable Business Model?”, Available at: http://www.journalism.net.in/is-indias-organized-retailsector-a-profitable-business-model-215/, Accessed on 7th November 2016.

[27] Nivedita Mookerji and Dilasha Seth, "Walmart Plans Tieups with Online Retailers”, Available at: http://www.business-

standard.com/article/companies/walmart-plans-tieups-withonline-retailers-116011400063_1.html, Accessed on 7th November, 2016. 